\title{
Intellectual Capital Dan Kinerja Keuangan Terhadap Nilai Perusahaan: Pada Industri Perbankan
}

\author{
Nosilia Fristiani ${ }^{1}$, Dyah Ani Pangastuti ${ }^{2}$, dan Harmono ${ }^{2}$ \\ ${ }^{1}$ Program Pascasarjana Universitas Merdeka Malang \\ Jl. Terusan Raya Dieng No. 57 Malang, 65145, Indonesia \\ ${ }^{2}$ Fakultas Ekonomi dan Bisnis Universitas Merdeka Malang \\ Jl. Terusan Raya Dieng No. 62-64 Malang, 65145, Indonesia
}

\section{Info Artikel}

\section{Keywords:}

Audit quality; Auditor Specialization; Detecting misstatement; Reporting misstatement; and Firm Reputation.
ISSN (print) : 2598-7763

ISSN (online): 2598-7771

$\triangle$ Corresponding Author:

Nosilia Fristiani

Tel. /Fax.

E-mail: noafrista@gmail.com

(c)) EY-NC-SA

\section{Abtract}

This study aims to examine and provide empirical evidence of the impact of client size and industry specialization on audit quality and the effect of audit quality on audit fees, reputation, and litigation both on audit-detecting misstatement quality and audit-reporting misstatement quality-analyzed based on client factors. This paper utilizes the perspective regulatory theory and signaling theory and is based on quantitative-causality research conducted by the survey method. Technique sampling is performed by purposive sampling. The results indicate that client size had a significant positive effect on the audit qualitydetecting misstatement but does not have any impact on the audit quality-reporting misstatements whereas industry specialization auditors have no effect on the audit qualitydetecting misstatement but have a significant effect on the audit quality-reporting misstatements. Clients may opt for the auditor that charges lower fees but can provide a positive signal for stakeholders or choose an auditor that is registered with BPK or OJK because such audit firms are more acceptable by stakeholders. As for the external auditors, the highquality audit is necessary to avoid the risk of litigation in addition to maintaining independence.

Citation: Fristiani, N., Pangastuti, D.A., dan Harmono (2020). Intellectual Capital Dan Kinerja Keuangan Terhadap Nilai Perusahaan: Pada Industri Perbankan. AFRE Accounting and Financial Review, 3 (1)

\begin{abstract}
Abstraks
Penelitian ini bertujuan untuk menganalisis dan menguji pengaruh modal intelektual pada nilai perusahaan melalui kinerja keuangan. Alat ukur Nilai perusahaan yaitu Price to Book Value (PBV), kinerja keuangan menggunakan return on equity (ROE), dan Intellektual capital menggunakan (VAICTM). Perusahaan perbankan yang sudah go public dijadikan objek penelitian. Jumlah sampel yang memenuhi kriteria sebanyak 32 perusahaan perbankan dengan periode pelaporan keuangan 2016-2018. Hasil penelitian menunjukkan intellectual capital (IC) memiliki pengaruh yang signifikan terhadap nilai perusahaan dengan kinerja keuangan, artinya semakin baik perusahaan dalam mengelola aset yang tidak berwujud yang bisa dikelola dengan baik dan menghasilkan laba dalam perusahaan tentu mempengaruhi pada nilai perusahaan
\end{abstract}

JEL Classification: G21, G23, G32 DOI: https://doi.org/10.26905/afr.v3i1.4223

\section{PENDAHULUAN}

Manajemen sebagai agen akan berusaha untuk selalu meningkatkan nilai perusahaan. Nilai perusahaan merupakan cerminan kemakmuran pemilik. Kemakmuran pemilik semakin tinggi, seiring peningkatan nilai perusahaan (Jiao, 2010), (Darminto, 2010), (Kellen, 2011), (Darwis, 2012), (Harrison \& Wicks, 2013), (Haryanto et al., 2018a), (Kurniawan, 2018), dan (Ananda, 2018). Perubahan lingkungan bisnis yang cepat, 


\section{Intellectual Capital Dan Kinerja Keuangan Terhadap Nilai Perusahaan: Pada Industri Perbankan}

Nosilia Fristiani, Dyah Ani Pangastuti, dan Harmono

menuntut manajemen dapat melakukan adaptasi dan antisipasi dengan cepat. Perkembangan teknologi dan komunikasi telah berdampak besar terhadap perekonomian. Perusahaan harus melakukan adaptasi terhadap perubahan lingkungan bisnis yang begitu cepat. Perusahaan perlu melakukan inovasi yang dapat mengikuti perkembangan lingkungan, khususnya dalam kecepatan perkembangan teknologi (Koellinger, 2008), (Wijaya, Ilhama, \& Paramastri, 2019), (Lee, Lee, \& Garrett, 2019). Perkembangan perusahaan saat ini sudah memasuki ke arah bisnis pengetahuan dan teknologi. Pengelolaan yang dapat dikelola dengan tepat dan sesuai dengan kebutuhan konsum-si masyarakat di era digital, merupakan tuntutan perusahaan dalam mencapai keberhasilan dalam mengelola manejemen pengetahuan (knowledge management) bagi perusahaan.

Kecepatan perubahan teknologi komunikasi, satu sisi menguntungkan perusahaan di sisi lain risiko perusahaan menjadi tinggi. Life cycle of product akan cenderung lebih cepat. Sehingga menuntut perusahaan melakukan inovasi dengan cepat, untuk memenangkan kompetisi. Penurunan pertumbuhan industri perbankan lebih banyak dipengaruhi oleh rendahnya perubahan teknologi ketimbanga factor efisiensi bank (Rusydiana, Laila, \& Sudana, 2019).

Perkembangan teknologi komunikasi telah mengubah ekosistem bisnis. Ekosistem bisnis dalam era digital lebih dinamis dan komplek (Winasis \& Riyanto, 2020). Model bisnis mengalami perubahan dengan sangat cepat. Semua aspek kehidupan kena dampak akibat perubahan teknologi komunikasi yang sangat cepat tersebut. Industri jasa keuangan salah satu industri yang terkena dampak dari perubahan teknologi tersebut (Yu, Rubanov, Vasylieva, \& Lyeonov, 2019), (Asongu et al., 2019). Perubahan teknologi yang cepat menuntut industri perbankan untuk dapat mengikutinya (Handayani \& Husnayetti, 2019). Bank yang lambat dalam mengikuti perkembangan teknologi akan ditinggal customernya.

Industri perbankan merupakan industri jasa yang sangat cepat perubahannya akibat perubahan teknologi. Kecepatan perubahan teknologi berdampak pada sektor perbankan, dan mendukung perusahaan untuk berkembang dalam bidang teknologi. Penggunaan teknologi yang handal akan dapat meningkatkan kinerja perusahaan. Bank dengan penggunaan teknologi yang semakin bagus menunjukkan sumber daya infromasi dan knowlwedge perusahaan yang semakin tinggi. Hal ini menunjukkan Intellectual capital bank yang semakin tinggi. Daya saing bank akan semakin meningkat seiring dengan peningkatan Intellectual capital, sehingga kinerja perusahaan akan semakin meningkat (Chen, 2005; Bayraktaroglu, 2019; Hirdinis, 2019; Mohapatra, Jena, \& Mitra, 2019; dan Xu \& Liu, 2020).

Intellectual capital merupakan informasi penting bagi investor. Semakin tinggi Intellectual capital suatu perusahaan menunjukkan daya perusahaan akan semakin tinggi, sehingga prospek perusahaan akan semakin baik. Intellectual capital yang tinggi merupakan sinyal positif bagi investor. Penelitian tentang intellectual capital terhadap nilai perusahaan telah banyak dilakukan, namun hasil penelitian menunjukkan hasil yang tidak konsisten. Penelitian Septiani, Holiawati, \& Ruhiyat, (2019) dan Poh et al., 2018 menunjukkan bahwa Intellectual capital berpengaruh positif terhadap nilai perusahaan. Sedangkan penelitian Dewi (2020) menunjukkan bahwa Intellectual capital tidak berpengaruh terhadap nilai perusahaan. Penelitian Hamdan (2018) menunjukkan bahwa intellectual capital tidak berpengaruh terhadap kinerja keuangan yang berbasis pada pasar. Intellectual capital berpengaruh positif terhadap kinerja perusahaan (Alipour, 2012; Fauzia \& Amanah, 2016; Devi, Budiasih, \& Badera, 2017; Budiarso, 2019; Bayraktaroglu, 2019, dan Hoang, at al, 2020). Sedangkan Penelitian Imaningati \& Vestari (2016) menunjukkan bahwa intellectual capital tidak berpengaruh terhadap nilai perusahaan.

Penelitian ini bertujuan untuk: 1) menganalisis pengaruh intellectual capital terhadap kinerja perusahaan, 2) menganalisis penga-ruh kinerja keuangan terhadap nilai perusahaan, 3) menganalisis pengaruh intellectual capital terhadap nilai perusahaan, dan 4) untuk menganalisis pengaruh intellectual capital terhadap nilai perusahaan melalui kinerja keuangan.

\section{PENGEMBANGAN HIPOTESIS}

\section{Intellectual Capital Terhadap Kinerja Keuangan}

Perusahan dengan modal intelektual yang kuat akan cenderung memiliki kemampuan daya saing yang semakin tinggi. Modal intelektual merupakan hasil dari pengetahuan sumber daya manusia yang dimiliki perusahaa. Sumber daya dengan pengetahuan yang tinggi akan mampu mengeksekusi strategi untuk memperoleh keunggulan kompetitif. Perusahaan yang memenangi persaingan bisnis akan berdampak kinerjanya meningkat (Soewarno \& Tjahjadi, 2020). 
Hasil penelitian menunjukkan bahwa intellectual capital mampu meningkatkan kinerja perusahaan ((Gama \& Mitariani, 2014; Gamayuni, 2015; Obeidat et al., 2017; Mulyasari \& Murwaningsari, 2019, dan (Soewarno \& Tjahjadi, 2020). Hipotesis penelitian sebagai berikut :

$\mathrm{H}_{1}$ : Intellectual capital memiliki pengaruh positif pada kinerja keuangan

\section{Kinerja Keuangan Terhadap Nilai Perusahaan}

Kinerja keuangan merupakan sinyal penting bagi investor. Perusahaan dengan kinerja yang baik menunjukkan perusahaan tersebut sehat dan prospeknya baik. Kinerja keuangan sering dipakai untuk mengukur keberhasilan perusahaan. Kinerja perusahaan mencerminkan fundamental perusahaan. Semakin baik kinerja perusahaan, maka fundamental perusahaan akan menjadi semakin kuat. Risiko investasi pada perusahaan dengan kinerja yang baik akan cenderung rendah. Sehingga kinerja perusahaan akan berdampak positif terhadap nilai perusahaan. Hasil penelitian menunjukkan bahwa kinerja perusahaan berpengaruh positif terhadap nilai perusahaan (Haryanto, 2014; Mohammad \& Bujang, 2019), dan Wardhani \& Hamidah, 2019).

$\mathrm{H}_{2}$ : Kinerja Keuangan berpengaruh positif terhadap Nilai Pasar

\section{Intellectual Capital Terhadap Nilai Perusahaan}

Seluruh investor pasti membaca laporan keuangan terlebih dahulu sebelum membeli saham yang beredar, hal yang diperlu diperhatikan utama para investor selalu memperhatikan tingkat kualitas sumberdaya manusia dan kemampuan dalam mengelola perusahaan yang dimiliki suatu entitas, karena apabila intellectual capital yang dimiliki entitas di perusahaan tinggi akan berdampak pada penyajian laporan keuangan yang bisa dipercaya dan mengakibatkan pada kemakmuran calon pemegang saham. intellectual capital akan mampu meningkatkan nilai perusahaan (Nadeem, Gan, \& Nguyen, 2018, dan (Soewarno \& Tjahjadi, 2020). Penelitian Juwita \& Angela (2016) menyatakan intellectual capital berpengaruh terhadap pasar.

$\mathrm{H}_{3}$ : Intellectual capital berpengaruh positif terhadap nilai perusahaan

\section{Intellectual Capital terhadap nilai perusahaan melalui Kinerja Kueangan}

Perusahaan dengan intellectual capital yang baik menunjnukkan perusahaan tersebut mampi mengeloa sumber daya yang dimiliki untuk meningkatkan daya saingnya (Anatan, 2000). Perusahaan dengan daya saing yang tinggi, akan berdampak pada kinerja keuangnnya meningkat pula. Penelitian yang dilakukan Fajarini \& Firmansyah, (2012); Oktari, Handajani, \& Widiastuty, (2016); Elfiswandi, Pratiwi, \& Melmusi, (2019) menunjukkan intellectual capital berpengaruh terhadap kinerja keuangan. Kinerja keuangan mampu memoderasi intellectual capital terhadap nilai perusahaan (Sayyidah \& Saifi, 2017).

$\mathrm{H}_{4}$ : Intellectual capital berpengaruh positif terhadap nilai perusahaan melalui kinerja keuangan.

\section{DATA DAN METODE}

Usaha mengkaji penelitian dengan cara deskriptif kuantitatif dengan penentuan sampel menggunakan purposive sampling. IC adalah variabel terkitat diukur dengan menggunakan nilai tambah, nilai perusahaan adalah variabel bebas yang diukur dengan price to book value, variabel moderating dalam penelitian ini yaitu kinerja keuangan yang diukur dengan return on equity. Dalam penelitian menggunakan analisis path. Sumber diperoleh dari BEI mulai tahun 2016 sampai dengan tahun 2018. Populasi yang dipilih adalah perusahaan perbankan di BEI sebanyak 43, dan jumlah sample yang dipilih sebanyak 32 . Variabel penelitian terdiri dari intellectual capital yang dikemukakan oleh Pulic (1998) dengan cara menentukan (VAIC ${ }^{\mathrm{TM}}$ ) yaitu: 1) Menentukan nilai VA (nilai tambah) dengan selisih pendapatan dikurangi dengan beban VA= OUT-IN Dimana: OUT=Jumlah dari pemasukan (penjualan), IN= Biaya dalam usaha bisnis tidak termasuk biaya karyawan; 2) Menentukan VACA, yaitu: hasil pengurangan antara Jumlah dari pemasukan (penjualan) dan biaya dalam usaha bisnis tidak termasuk biaya karyawan dibagi dengan seluruh jumlah harta yang dimiliki; 3) Menentukan VAHU, yaitu hasil pengurangan antara Jumlah dari pemasukan (penjualan) dan biaya dalam usaha bisnis tidak termasuk biaya karyawan dibagi dengan jumlah harta pada pekerja (honor); 4) Menentukan STVA, yaitu hasil pengurangan antara Jumlah dari pemasukan (penjualan) dan biaya dalam usaha bisnis tidak termasuk biaya karyawan dikurangi dengan jumlah jumlah harta pada pekerja (honor) dan dibagi dengan nilai tambah. 5) Menentukan (VAICTM) yaitu hasil total dari keseluruhan indikator VACA, VAHU, STVA. Nilai perusahaan, meng- 


\section{Intellectual Capital Dan Kinerja Keuangan Terhadap Nilai Perusahaan: Pada Industri Perbankan Nosilia Fristiani, Dyah Ani Pangastuti, dan Harmono}

gunakan rumus PBV sebagai indikator dalam menentukan nilai perusahaan (Brigham dan Houston, 2006): PBV= Harga per Lembar Saham/ Nilai Buku per lembar Saham. Kinerja keuangan, digunakan return on equity.

\section{HASIL}

Hasil penelitian deskripsi data disajaikan pada tabel 1. menunjukkan bahwa kinerja keuangan, intellectual capital memiliki pengaruh terhadap nilai perusahaan. Hal ini memperkuat teori dari Resources Based Theory dan Agency Theory, apabila sumber daya perusahaan dikelola dengan baik akan menciptakan value added dan memberikan informasi yang reliabilitas bagi perusahaan melalui kinerja yang akan mempengaruhi nilai perusahaan. Sampel digunakan sebanyak 32 entitas selama tiga tahun dengan jumlah data sebanyak 96 yang akan disajikan dalam bentuk data olah spss sebagai berikut:

Tabel 1. Statistik Deskriptif Hasil Penelitian

\begin{tabular}{lcllll}
\hline & N & Minimum & Maximum & Mean & Std. Deviation \\
\hline IC (VAICTM) & 96 & 3,13 & 17566,77 & 1682,4516 & 2930,38986 \\
Kinerja Keuangan (ROE) & 96 & 0,32 & 73,10 & 8,5457 & 8,40955 \\
Nilai Perusahaan (PBV) & 96 & 0,2 & 8,0 & 2,238 & 1,8414 \\
\hline
\end{tabular}

Tabel 2. Pengaruh Langsung, Tidak Langsung, dan Total

\begin{tabular}{|c|c|c|c|c|}
\hline Variabel & Pengaruh Langsung & $\begin{array}{l}\text { Pengaruh } \\
\text { Langsung }\end{array}$ & Tidak & Pengaruh Total \\
\hline IC $($ VAICTM $) \rightarrow$ Kinerja keuangan $(\mathrm{ROE})$ & $0,288^{*}$ & - & & - \\
\hline $\begin{array}{l}\begin{array}{l}\text { Intellectual capital } \\
\text { perusahaan }(\mathrm{PBV})\end{array} \\
\text { (VICTM) }\end{array}$ & $0,497^{*}$ & - & & - \\
\hline $\begin{array}{l}\text { Kinerja keuangan } \\
\text { perusahaan }(\mathrm{PBV})\end{array}$ & $0,189^{*}$ & - & & - \\
\hline $\begin{array}{l}\text { IC }(\mathrm{VAICTM}) \rightarrow \text { Kinerja keuangan }(\mathrm{ROE}) \rightarrow \\
\text { Nilai perusahaan }(\mathrm{PBV})\end{array}$ & 0,497 & $0,288 \times 0,18$ & $=0,054$ & 0,551 \\
\hline
\end{tabular}

\section{Keterangan: * Signifikan level 0,05}

Berdasarkan table 1 Value added coefisien dengan Std. Deviation 2930,38986, kinerja keuangan Std. Deviation 8,40955 dan nilai perusahaan nilai Std. Deviation 1,8414 dengan masing masing data nilai $\mathrm{N}$ sejumlah 96 memiliki arti bahwa semakin tinggi Standar deviasi maka semakin baik perusahaan dalam mengelolan sumberdaya yang dimiliki yang bias diolah sebagai laba yang nantinya berdampak pada ketertarikan pada minat daya beli investor.

Pada tabel 2, terlihat jumlah dari pengaruh total $\geq$ daripada pengaruh langsung. Uji tersebut menunjukkan kinerja berpotensi sebagai variabel intervening. Berdasarkan tabel 2 menunjukkan Intellectual capital $\left(\mathrm{VAIC}^{\mathrm{TM}}\right.$ ) berpengaruh terhadap kinerja keuangan. Kinerja keuangan berpengaruh terhadap Nilai Perusahaan. Intellectual capital (VAIC ${ }^{\mathrm{TM}}$ ) berpengaruh terhadap nilai perusahaan. Intellectual capital berpengaruh terhadap nilai perusahaan melalui kinerja keuangan

\section{PEMBAHASAN}

\section{Intellectual Capital terhadap Kinerja Keuangan}

Hasil analisis menunjukkan bahwa perusahaan sektor perbankan bisa mengelola inte- llectual capital dengan baik yang tercermin dari tiga komponen VAIC ${ }^{\mathrm{TM}}$ yaitu a) human capital seperti ketrampilan yang dimiliki karyawan dalam dunia usaha, b) structural capital contohnya standarisari yang diterapkan di entitas secara sehat dan benar dilakukan untuk menunjang keberhasilan kinerja. c) customer capital, seperti pelayanan yang baik terhadap konsumen dan bagaiman kita memberikan kualitas dan loyalitas produk ke konsumen agar perusahaan mendapat pengaruh dan nama baik dari pelanggan yang bisa terkenal di pasar.

Intellectual capital terbukti bisa memberikan value bagi perusahaan khususnya di sektor perbankan dalam mengelolan sumberdaya yang dimiliki. Apabila sumberdaya perusahaan dapat dikelola dengan baik pasti akan meningkatkan kinerja perusahaan.

Teknologi perbankan yang sangat cepat, peran intellectual capital berpengaruh pada kinerja bank. Bank dengan pengelolaan intellectual capital yang baik telah mampu meningkatkan daya saing bank (Clarke, Seng, \& Whiting, 2011), (Alipour, 2012), (Wang, Wang, \& Liang, 2014), (Gamayuni, 2015), (Mohammad \& Bujang, 2019) dan (Xu \& Liu, 2020). Bank sebagai industri jasa, maka peran intellectual capital menjadi sangat penting. 


\section{Kinerja Keuangan terhadap Nilai Perusahaan}

Secara empiris bahwa nilai perusahaan yang baik dipengaruhi oleh kinerja dari perusahaan. Perusahaan dengan kinerja yang baik menunjukkan fundamental perusahaan tersebut sehat dan kuat. Sehingga risiko yang terjadi rendah. Investor akan merasa aman Ketika menanamkan dananya di perusahaan tersebut. Keberhasilan perusahaan dalam mencapai laba akan berpengaruh terhadap calon investor yang ingin membeli saham.

Profitabilitas merupakan indikator kinerja perusahaan. Perusahaan dengan kinerja yang baik, menunjukkan perusahaan tersebut sehat. Perusahaan dengan kinerja yang baik kana cenderung mampu tumbuh dan berkembang dimasa yang akan datang. Investasi pada perusahaan-perusahaan dengan fundamental kuat akan mampu meningkatkan nilai invetasi di masa yang akan datang. Sehingga perusahaan dengan kinerja yang baik merupakan sinyal positif bagi investor (Kodongo, Mokoaleli-Mokoteli, \& Maina, 2015; Haryono \& Paminto, 2015; Haryanto et al., 2018b; dan (Xu \& Liu, 2020). Hal ini akan berdampak pada nilai perusahaan yang meningkat. Ekspektasi investor terhadap perusahaan akan cenderung meningkat.

\section{Intellectual Capital Terhadap Nilai Perusahaan}

Apabila suatu entitas bisa mengelola knowlegde asset dengan baik akan memberikan manfaat pada peningkatan nilai perusahaan sesuai yang diinginkan. Sampai sejauh ini investor membaca bahwa perusahaan yang memiliki kualitas knowlede asset/ IC yang tinggi mampu memberikan kontribusi pada nilai pasar. Pernyataan diatas bisa dijadikan informasi bahwa investor lebih memperhatikan perusahaan yang memiliki IC yang tinggi yang bisa dikelola secara efektif dan efisien yang bisa meningkatkan PBV. Nilai pasar yang tinggi menentukan nilai perusahaan. Hasil penelitian sama dengan hasil dari (Zuliyati \& Arya, 2011), Juwita (2016), (Poh et al., 2018), dan (Xu \& Liu, 2020) bahwa intellectual capital berpengaruh terhadap nilai perusahaan. Namun hasil penelitian tidak sejalan dengan Marcelia \& Purnomo (2016).

\section{Intellectual Capital Terhadap Nilai Perusahaan Melalui Kinerja Keuangan}

Kinerja keuangan sebagai variabel intervening antara variabel intellectual capital terhadap nilai perusahaan, artinya intellectual capital berpo- tensi memberikan pengaruh pada nilai pasar. Kinerja keuangan mampu memoderasi intellectual capital pengaruhnya terhadap nilai perusahaan. Hal ini menunjukkan bahwa nilai perusahaan dapat ditingkatkan dengan intellectual capital melalui kinerja keuangan. Intellectual capital yang dimiliki perusahaan akan meyakinkan investor, melalui peningkatan kinerja keuangan.

Hasil penelitian ini sejalan dengan Hadiwijaya (2013) yang membuktikan bahwa kinerja keuangan berpengaruh secara positif sebagai variable intervebing antara intellectual capital dan nilai perusahaan.

\section{SIMPULAN DAN SARAN}

Tujuan penelitian ini adalah untuk menganalisis pengaruh intellectual capital terhadap kinerja perusahaan, pengaruh kinerja keuangan terhadap nilai perusahaan, dan pengaruh intellectual capital terhadap nilai perusahaan, dan untuk menganalisis pengaruh intellectual capital terhadap nilai perusahaan melalui kinerja keuangan. Hasil penelitian menunjukkan bahwa intellectual capital berpengaruh terhadap kinerja keuangan perbankan. Perusahaan yang mampu mengeloa intellectual capital dengan baik akan berpengaruh terhadap kinerja. Kinerja keuangan berpengaruh terhadap nilai perusahaan. Intellectual capital berpengaruh terhadap nilai perusahaan Kinerja keuangan memdiasi pengaruh intellectual capital dan nilai perusahaan.

Penelitian yang dilakukan ini terbatas pada industri perbankan dengan tidak memisahkan aset bank. Untuk penelitian selanjutnya dapat dilakukan dengan melakukan analisis dengan membedakan asset bank. Selain itu dapat memasukkan variabel lain sebagai variabel kontrol risiko sistematis.

\section{DAFTAR PUSTAKA}

Alipour, M. (2012). The effect of intellectual capital on firm performance: an investigation of Iran insurance companies. 16(1), 53-66. https://doi.org/10.1108/1368304121120467 1

Ananda, A. F. (2018). Stuktur Modal, Kinerja Perusahaan, dan Altman Z-Score Pengaruhnya Terhadap Ekspektasi Investor. AFRE (Accounting and Financial Review), 1(1), 9-16. https://doi.org/10.26905/afr.v1i1. 2285

Anatan, L. (2000). Manajemen Modal Intelektual: Strategi Memaksimalkan Nilai Modal Intelektual 
Intellectual Capital Dan Kinerja Keuangan Terhadap Nilai Perusahaan: Pada Industri Perbankan Nosilia Fristiani, Dyah Ani Pangastuti, dan Harmono

Dalam Technology Driven. 1-10.

Asongu, S. A., Anyanwu, J. C., Tchamyou, V. S., Asongu, S. A., Anyanwu, J. C., \& Tchamyou, V. S. (2019). Information Technology for Development Technology-driven information sharing and conditional financial development in Africa. 1102. https://doi.org/10.1080/ 02681102.2017.1311833

Bayraktaroglu, A. E. (2019). Intellectual capital and firm performance: an extended VAIC model. (Ic). https://doi.org/10.1108/JIC-12-20170184

Budiarso, N. S. (2019). Intellectual Capital in Public Sector. Accountability, 08(01), 42-50.

Chen, M. (2005). An empirical investigation of the relationship between intellectual capital and firms ' market value and financial performance. 6(2), 159-176. https://doi.org/10.1108/ 14691930510592771

Clarke, M., Seng, D., \& Whiting, R. H. (2011). Intellectual capital and firm performance in Australia. Journal of Intellectual Capital, 12(4), 505-530. https://doi.org/10.1108/ 14691931111181706

Darminto. (2010). Pengaruh Faktor Eksternal dan Berbagai Keputusan Keuangan terhadap Nilai Perusahaan. Jurnal Aplikasi Manajemen, 8(1), 138-152.

Darwis, H. (2012). Manajemen Laba Terhadap Nilai Perusahaan Dengan Corporate Governance Sebagai Pemoderasi. Jurnal Keuangan Dan Perbankan, 16(1), 45-55. https://doi.org/10.1016/00092509(79)85024 $-1$

Devi, S., Budiasih, I. G. N., \& Badera, I. D. N. (2017). Pengaruh Pengungkapan Enterrise Management Dan Pengungkapan Intelektual Capital Terhadap Nilai Perusahaan. Jurnal Akuntansi Dan Keuangan Indonesia, 14(1), 20-45.

Dewi, E. P. (2020). Pengaruh Intellectual Capital Dan Kualitas Audit Terhadap Nilai Perusahaan Dengan Dividend Policy Sebagai Variabel Moderasi. ULTIMA Accounting, 11(2, Desember), 142-159. https://doi.org/http://ejournals.umn.ac.id /index.php/Akun/article/view/1428/885

Elfiswandi, Pratiwi, H., \& Melmusi, Z. (2019). The influence of intellectual capital on financial performance:A Study on Banking Companies Listed in Indonesia Stock Exchange. Review of Integrative Business and Economics Research, 8(2), 300-312. https://doi.org/10.2991/insyma-18.2018.15
Fajarini, I. S. ., \& Firmansyah, R. (2012). Pengaruh Intellectual Capital Terhadap Kinerja Keuangan Perusahaan (Studi Empiris Perusahaan Lq 45). Jurnal Dinamika Akuntansi, 4(1), 1-12. https://doi.org/10.15294/jda.v4i1.1954

Fauzia, N., \& Amanah, L. (2016). Pengaruh Intellectual Capital, Karakteristik Perusahaan, Dan Corporate Social Responsibility Terhadap Nilai Perusahaan. Jurnal Ilmu Dan Riset Akuntansi, 5(4), 1-22.

Gama, A. W. S., \& Mitariani, N. W. E. (2014). Modal intelektual terhadap efisiensi dan kinerja pasar perbankan di indonesia. Finance and Banking Journal, 16(1), 77-86.

Gamayuni, R. R. (2015). The Effect Of Intangible Asset, Financial Performance And Financial Policies On The Firm Value. 4(01), 202-212.

Hamdan, A. (2018). Intellectual capital and firm performance: Differentiating between accounting-based and market-based performance. International Journal of Islamic and Middle Eastern Finance and Management, 11(1), 139-151. https://doi.org/ 10.1108/IMEFM-02-2017-0053

Handayani, T., \& Husnayetti. (2019). Analisis Penerimaan Teknologi Mobile Banking Pada Nasabah Wanita Karir Di Bank Rakyat Indonesia Cabang Ciputat. IJEA Indonesia Journal of Economics Application, 1(2), 150154.

Harrison, J. S., \& Wicks, A. C. (2013). Stakeholder Theory, Value, and Firm Performance. Business Ethics Quarterly, 23(1), 97-124. https://doi.org/10.5840/beq20132314

Haryanto, S. (2014). Identifikasi Ekspektasi Investor Melalui Struktur Modal, Profitabilitas, Ukuran Perusahaan dan GCPI. Jurnal Dinamika Manajemen Http://Journal.Unnes.Ac.Id/Nju/Index.Php/Jdm ANALISIS, 5(2), 183-1199. https://doi.org/10.1017/СВО978110741532 4.004

Haryanto, S., Rahadian, N., Fatima, M., Mbapa, I., Nesty, E., \& Vivi, K. (2018a). Kebijakan Hutang, Ukuran Perusahaan dan Kinerja Keuangan Terhadap Nilai Perusahaan: Industri Perbankan di Indonesia. AFRE Accounting and Financial Review, 1(2), 62-70.

Haryanto, S., Rahadian, N., Fatima, M., Mbapa, I., Nesty, E., \& Vivi, K. (2018b). Kebijakan Hutang, Ukuran Perusahaan dan Kinerja Keuangan Terhadap Nilai Perusahaan: Industri Perbankan di Indonesia. 1(2), 62-70. 
Haryono, U., \& Paminto, A. (2015). Corporate Governance and Firm Value: The Mediating Effect of Financial Performance and Firm Risk. European Journal of Business and Management, 7(35), 18-24.

Hirdinis. (2019). Capital Structure and Firm Size on Firm Value Moderated by Profitability. International Journal of Economics and Business Administration, 7(1), 174-191.

Imaningati, S., \& Vestari, M. (2016). Disclosure Atas Management Statement, Intellectual Capital, Dan Corporate Social Responsibility Terhadap Nilai Perusahaan. Jurnal Akuntansi Indonesia, 5(1), 99-114.

Jiao, Y. (2010). Stakeholder welfare and firm value. Journal of Banking and Finance, 34(10), 2549-2561. https://doi.org/10.1016/ j.jbankfin.2010.04.013

Juwita, R., \& Angela, A. (2016). Pengaruh Intellectual Capital Terhadap Nilai Perusahaan pada Perusahaan Indeks Kompas 100 di Bursa Efek Indonesia. Jurnal Akuntansi, 8(1), 1-15.

Kellen, P. B. (2011). Struktur Kepemilikan, Profitabilitas, Dan Risiko Perusahaan Terhadap Struktur Modal Dan Nilai Perusahaan. Jurnal Keuangan Dan Perbankan, 15(1), 201-212.

Kodongo, O., Mokoaleli-Mokoteli, T., \& Maina, L. (2015). Capital structure, profitability and firm value: panel evidence of listed firms in Kenya. African Finance Journal, 17(1), 1-20. https://doi.org/10.3386/w19846

Koellinger, P. (2008). The relationship between technology, innovation, and firm performanceEmpirical evidence from e-business in Europe. 37, 1317-1328. https://doi.org/10.1016/ j.respol.2008.04.024

Kurniawan, Y. (2018). Indonesia Most Trusted Company dan Nilai Perusahaan. AFRE (Accounting and Financial Review), 1(1), 1-8. https://doi.org/10.26905/afr.v1i1.2267

Lee, R., Lee, J., \& Garrett, T. C. (2019). Synergy e ff ects of innovation on fi $\mathrm{rm}$ performance is. Journal of Business Research, 99(June). https://doi.org/10.1016/j.jbusres.2017.08.03 2

Marcelia, E., \& Purnomo, B. S. (2016). Pengaruh Nilai Tambah Modal Intelektual Dan Pengungkapan Modal Intelektual Terhadap Nilai Perusahaan (Studi Pada Perusahaan Perbankan Yang Terdaftar Di Bursa Efek Indonesia). Jurnal ASET (Akuntansi Riset), $8(1)$, 29. https://doi.org/10.17509/ jaset.v8i1.4019

Mohammad, H. S., \& Bujang, I. (2019). Performance of Malaysian financial firms: An intellectual capital perspective using MVAIC model. Asian Economic and Financial Review, 9(7), 752-765. https://doi.org/ 10.18488/journal.aefr.2019.97.752.765

Mohapatra, S., Jena, S. K., \& Mitra, A. (2019). Intellectual capital and firm performance: evidence from Indian banking sector. Applied Economics, 00(00), 1-14. https://doi.org/10.1080/00036846.2019.164 5283

Mulyasari, W., \& Murwaningsari, E. (2019). Intellectual Capital, Competitive Advantage, Financial Performance And Company Value Among Banking Industries In Indonesia. 6(4), 78-89.

Nadeem, M., Gan, C., \& Nguyen, C. (2018). The Importance of Intellectual Capital for Firm Performance: Evidence from Australia. Australian Accounting Review, 28(3), 334-344. https://doi.org/10.1111/auar.12184

Obeidat, B. Y., Abdallah, A. B., Aqqad, N. O., Hakeem, A., Akhoershiedah, O. M., \& Maqableh, M. (2017). The Effect of Intellectual Capital on Organizational Performance: The Mediating Role of Knowledge Sharing. 1-27. https://doi.org/10.4236/cn.2017.91001

Oktari, I. G. A. P., Handajani, L., \& Widiastuty, E. (2016). Determinan Modal Intelektual (Intellectual Capital) pada Perusahaan Publik di Indonesia dan Implikasinya terhadap Nilai Perusahaan. Simposium Nasional Akuntansi XIX, 1-29.

Poh, L. T., Kilicman, A., Nur, S., Ibrahim, I., Poh, L. T., Kilicman, A., Ibrahim, I. (2018). On intellectual capital and financial performances of banks in Malaysia On intellectual capital and financial performances of banks in Malaysia. Cogent Economics \& Finance, 16(1). https://doi.org/10.1080/23322039.2018.145 3574

Rusydiana, A. S., Laila, N., \& Sudana. (2019). Efisiensi dan Produktivitas Industri Perbankan pada Sistem Moneter Ganda di Indonesia. Jurnal Siasat Bisnis, 23(1), 50-66. https://doi.org/10.20885/jsb.vol23.iss1.art5 Sayyidah, U., \& Saifi, M. (2017). Pengaruh Intellectual Capital Terhadap Nilai Perusahaan Dengan Profitabilitas Sebagai Variabel Moderasi (Studi Pada Perusahaan Sub Sektor Property Dan Real Estate Di 
Intellectual Capital Dan Kinerja Keuangan Terhadap Nilai Perusahaan: Pada Industri Perbankan Nosilia Fristiani, Dyah Ani Pangastuti, dan Harmono

Bursa Efek Indonesia Periode 2013-2015).

Jurnal Administrasi Bisnis S1 Universitas Brawijaya, 46(1), 163-171.

Septiani, E., Holiawati, \& Ruhiyat, E. (2019).

Environmental Performance, Intellectual Capital, Praktik Penghindaran Pajak Dan Nilai Perusahaan. Jurnal Bisnis Dan Akuntansi, 21(1), 61-70.

Soewarno, N., \& Tjahjadi, B. (2020). Measures that matter : an empirical investigation of intellectual capital and financial performance of banking firms in Indonesia. (2014). https://doi.org/10.1108/JIC-09-2019-0225

Wang, Z., Wang, N., \& Liang, H. (2014). Knowledge sharing, intellectual capital and firm performance. Management Decision, 52(2), 230-258. https://doi.org/10.1108/ MD-02-2013-0064

Wardhani, P. P. C., \& Hamidah. (2019). The signalling of Sustainability reporting award in Indonesia and its effects on financial performance and firm value. International Journal of Innovation, Creativity and Change, $9(8), 14-32$.

Wijaya, R. A., Ilhama, N., \& Paramastri, B. (2019). Pentingnya Pengelolaan Inovasi Dalam Era Persaingan. 5(2), 217-227.

Winasis, S., \& Riyanto, S. (2020). Transformasi Digital di Industri Perbankan Indonesia: Impak pada Stress Kerja Karyawan. Iqtishadia Jurnal Ekonomi \& Perbankan Syariah, 7(1). https://doi.org/10.1905/iqtishadia. v7i1.3162

Xu, J., \& Liu, F. (2020). The Impact of Intellectual Capital on Firm Performance: A Modified And Extended VAIC Model. Journal of Competitiveness, 12(1), 161-176.

Yu, B., Rubanov, P., Vasylieva, T., \& Lyeonov, S. (2019). The Influence of Industry 4.0 on Financial Service: Determinan of Alternatif Finance Development. Polish Journal of Management Studies, 19(1), 70-93. https://doi.org/10.17512/pjms.2019.19.1.06

Zuliyati, \& Arya, N. (2011). Intellectual capital and company' $\mathrm{s}$ financial performance. Dinamika Keuangan Dan Perbankan, 3(1), 113 125. 